\title{
Modelling of aflatoxin G1 reduction by kefir grain using response surface methodology
}

Farzaneh Ansari ${ }^{1}$, Faramarz Khodaiyan ${ }^{1 *}$, Karamatollah Rezaei ${ }^{2}$ and Anosheh Rahmani ${ }^{3}$

\begin{abstract}
Aflatoxin G1 (AFG1) is one of the main toxic contaminants in pistachio nuts and causes potential health hazards. Hence, AFG1 reduction is one of the main concerns in food safety. Kefir-grains contain symbiotic association of microorganisms well known for their aflatoxin decontamination effects. In this study, a central composite design (CCD) using response surface methodology (RSM) was applied to develop a model in order to predict AFG1 reduction in pistachio nuts by kefir-grain (already heated at 70 and $110^{\circ} \mathrm{C}$ ). The independent variables were: toxin concentration $\left(X_{1}: 5,10,15,20\right.$ and $\left.25 \mathrm{ng} / \mathrm{g}\right)$, kefir-grain level $\left(X_{2}: 5,10,20,10\right.$ and $\left.25 \%\right)$, contact time $\left(X_{3}: 0,2,4\right.$, 6 and $8 \mathrm{~h}$ ), and incubation temperature $\left(\mathrm{X}_{4}: 20,30,40,50\right.$ and $\left.60^{\circ} \mathrm{C}\right)$. There was a significant reduction in AFG1 $(p<0.05)$ when pre-heat-treated kefir-grain used. The variables including $X_{1}, X_{3}$ and the interactions between $\mathrm{X}_{2}-\mathrm{X}_{4}$ as well as $\mathrm{X}_{3}-\mathrm{X}_{4}$ have significant effects on AFG1 reduction. The model provided a good prediction of AFG1 reduction under the assay conditions. Optimization was used to enhance the efficiency of kefir-grain on AFG1 reduction. The optimum conditions for the highest AFG1 reduction (96.8\%) were predicted by the model as follows: toxin concentration $=20 \mathrm{ng} / \mathrm{g}$, kefir-grain level $=10 \%$, contact time $=6 \mathrm{~h}$, and incubation temperature $=30^{\circ} \mathrm{C}$ which validated practically in six replications.
\end{abstract}

Keywords: Aflatoxin G1, Pistachio nut, Predictive modelling, Kefir-grain, Optimization

\section{Background}

Aflatoxin G1 (AFG1) is a secondary toxic metabolite of the fungi Aspergillus parasiticus. Monitoring data indicate that humans and animals may be exposed to health problems via the ingestion of AFG1-contaminated foods and feeds. This toxin has been identified as a mutagenic agent to humans [1]. The International Agency for Research on Cancer reported that there was sufficient evidence in animals for the carcinogenicity of naturally occurring AFG1 [2]. This kind of aflatoxin also caused liver tumours in experimental animals, but generally at a lower incidence than aflatoxin mixtures (AFs) and/or aflatoxin B1 (AFB1) [3]. The rank order of toxicity of AFs is AFB1 > AFG1 > AFB2 > AFG2 [4]. Therefore, AFG1 is the second most important toxic agent among AFs and reducing its bioavailability is of great interest for human safety.

Pistachio nuts are one of the important foodstuffs with the highest risk of AFs contamination [5]. The maximum

\footnotetext{
*Correspondence: khodaiyan@ut.ac.ir

${ }^{1}$ Bioprocess and Biodetection Laboratory (BBL), Department of Food Science, Engineering and Technology, University of Tehran, 31587-77871 Karaj, Iran Full list of author information is available at the end of the article
}

legal limit of AFG1, not only in Iran but also in the European Union (EU), has not been specified. The allowed level of AFG1 was established altogether with other AFs (AFB1, AFB2 and AFG2) and expressed as total aflatoxin (AFT) [6,7]. Iran is the primary pistachio nut-producing country, and produced almost 472,097 tons of pistachio in 2012 [8].

Dini and co-workers reported that $23.5 \%$ of the Iranian pistachio nuts were contaminated with AFT higher than the maximum tolerated level (MRL) during the years 2009-2011 [9]. Preventive physical and chemical methods have been proposed to detoxify AFs [10-14]. These detoxification methods have many limitations, such as the loss of nutritional value of foodstuffs, undesirable health effects of the by-products, high energy consumption and expensive equipment requirements. Nowadays, biological methods by utilizing isolates of bacteria and yeast are used to reduce bioavailability of AFs in different food commodities [15-18].

Kefir-grains are a symbiotic association of microorganisms well known for their probiotic microflora due to aflatoxin decontamination effects. A number of investigations 
have already reported the biological degradation of AFs by Lactobacillus casei [19], Lactobacillus plantarum [20] and Saccharomyces cerevisiae [21], which were similar to those in kefir-grain [22]. Studies have shown that detoxification occurs by binding the AFs to the microorganism cell-wall structure and involve the formation of a reversible complex between the toxin and microorganism surface, without chemical modification of the toxin $[18,23]$. Based on the above-mentioned studies, most of the published investigations are in the field of AFB1 decontamination and despite the adverse effect of AFG1 in human safety, no studies have been reported on the possibility of AFG1 decontamination by kefir grains, none in pistachio nuts.

The purposes of the current study were as follows: (i) to investigate the effect of kefir-grain on reduction of AFG1 in pistachio nuts; (ii) to predict a model for AFG1 reduction by kefir-grain, if it has significant effect; and (iii) to optimize the method by using statistical experimental methods.

\section{Materials and methods \\ Preparation of pistachio nuts}

Pistachio nuts were purchased from a wholesaler in Tehran, Iran. The consignments were mixed together and stored in zip-locked plastic bags at $4^{\circ} \mathrm{C}$ during the experiment. Preparations of subsamples were carried out at the Mycotoxin Laboratory, Department of Food Science \& Technology, Standard Research Institute, Karaj, Iran, and the Scientific and Research Laboratory of Farogh, located in Tehran, Iran.

For minimising the subsampling errors in AFG1 analysis, water slurry of pistachio nut samples were prepared in a 1:1 ratio. In order to provide a uniform paste, the mixture was ground using a slurry machine. Finally, each sample (containing: 12.5 gr pistachio nuts kernel + $12.5 \mathrm{gr}$ shell $+25 \mathrm{~mL}$ water) was taken for further experiments. The samples were analysed by high-performance liquid chromatography (HPLC).

\section{Maintenance, activation and treatment of kefir-grains}

Kefir grains were obtained from the Microorganism Bank, Department of Food Science, Engineering \& Technology, Tehran University. The grains were kept in skimmed milk at room temperature at $23 \pm 2^{\circ} \mathrm{C}$, and the medium was exchanged for fresh skimmed milk daily to maintain grain viability. In order to increase the kefir-grain biomass, the grains were activated [24] and kept at $4^{\circ} \mathrm{C}$ for short-term storage [25]. Kefir-grains were then ground using a high speed blender (minimum 6000, rpm) and mixed with an equal amount of water. Three levels of heating treatment $(\mathrm{N}=$ non-heated at room temperature; $\mathrm{H}=$ heated at $70 \pm$ $2^{\circ} \mathrm{C}$ using a heating device for $5-10 \mathrm{~min}$; and $\mathrm{U}=$ heated at $110 \pm 2^{\circ} \mathrm{C}$ using an autoclave for $10 \mathrm{~min}$ ) were utilized to obtain the maximum activity of grains.

\section{Sample preparation}

For preparing test samples, each (50 gr) pistachio paste portion was thoroughly contaminated with the working AFG1 solutions $(5,10,15,20$ and $25 \mathrm{ng} / \mathrm{g})$. After that, the contaminated samples were inoculated with different amounts of homogenised treated-kefir grain $(2.5,5.0$, $7.5,10.0$ and $12.5 \mathrm{gr}$; respectively equal to $5,10,15,20$ and $25 \%$ pistachio past sample). The samples were shaken well and incubated at different incubation temperatures $\left(20,30,40,50\right.$ and $\left.60^{\circ} \mathrm{C}\right)$ and contact times $(0,2,4,6$ and $8 \mathrm{~h}$ ) while other factors were kept constant.

\section{Chemicals and reagents}

Standard solution of AFG1 was obtained from SigmaAldrich Chemical Company (USA). Methanol, n-hexane, sodium chloride, acetonitrile, nitric acid, potassium bromide, phosphate-buffered saline were from Merck, Darmstadt, Germany. To produce mobile phase, water $(600 \mathrm{~mL})$, methanol $(300 \mathrm{~mL})$, acetonitrile $(200 \mathrm{~mL})$, $350 \mu \mathrm{L}$ nitric acid $(4 \mathrm{~mol} / \mathrm{L})$ and $120 \mathrm{mg}$ potassium bromide were mixed. All solvents used for the experiments were of either HPLC or analytical grade.

\section{Extraction and cleanup of residual AFG1}

The extraction and cleanup of residual AFG1 was performed using AOAC official method 999.07 with some minor modification [26]. Each sample was extracted using $180 \mathrm{~mL}$ of methanol and $50 \mathrm{~mL} n$-hexane. The extract was diluted by $130 \mathrm{~mL}$ water and then filtered through a glass microfiber filter. Aflatest immune-affinity column (IAC, Faroogh Scientific and Research Laboratory) was utilized to clean up the samples. For activation of IAC, $10 \mathrm{~mL}$ of phosphate buffer saline passed through it. Then, $75 \mathrm{~mL}$ of the filtrate passed through the IAC at a flow rate of 1 drop per second. The column was washed with $15 \mathrm{~mL}$ water and dried by applying vacuum for $10 \mathrm{~s}$. Finally, elution of IAC was performed using methanol in two steps. First, $1500 \mu \mathrm{L}$ methanol was poured on the IAC and allowed to pass through by gravity. After one min the eluate was collected in a vial and finally diluted by $1500 \mu \mathrm{L}$ water before being analyzed by HPLC.

\section{Aflatoxin $\mathrm{G} 1$ analysis}

Reversed-phase HPLC using post column derivatization involving bromination was applied to determine AFG1 [26,27]. The HPLC system (Waters 2695) was equipped with pump, a Waters 2475 multi-fluorescence detector and a Chromolit $\mathrm{C}_{18}$ analytical column (Merck Chemical Company, Darmstadt, Germany, $200 \mathrm{~cm} \times 4.6 \mathrm{~mm} \times$ $4 \mu \mathrm{m})$. An electrochemical PCD system was applied using Farlib ${ }^{\circ}$ EDC cell (Faroogh Scientific and Research Laboratory) for bromination purposes. The flow rate was set at $2.5 \mathrm{~mL} / \mathrm{min}$. The detector was operated at wavelengths of 365 and $435 \mathrm{~nm}$ as excitation and emission wavelengths, 
respectively. The limit of detection for AFG1 determination was $0.1 \mathrm{ng} / \mathrm{g}$.

\section{Experimental design and statistical analysis}

In this investigation, central composite design (CCD) using response surface methodology (RSM) was employed to determine the more significant factors among variables which predicted to have an effect on AFG1 reduction $[28,29]$. Thus, 31 experimental runs (as shown in Table 1) were designed using different variables: toxin concentration $\left(\mathrm{X}_{1}\right)$, kefir grain level $\left(\mathrm{X}_{2}\right)$; contact time $\left(\mathrm{X}_{3}\right)$; incubation temperature $\left(\mathrm{X}_{4}\right)$. The role of other variables (such as acid-treated kefir-grain) which may affect the reduction of AFG1 did not investigate.

Data analysis was performed using the $\mathrm{R}$ statistical software (version R-3.0.3). Tukey statistical test was used for comparing the means. Significant factors affecting the response were examined using analysis of variance (ANOVA). The results were fitted with a polynomial equation by a multiple regression technique. Theoretical validation of the model for the predicted values of six replicates under optimal conditions was performed by running the two-sample $t$-test.

\section{Results and discussion}

\section{Preliminary investigation}

A preliminary study was performed to determine the effect of kefir-grain on AFG1 reduction from pistachio nuts. Thus, an experiment was performed on contaminated test samples with a constant concentration of AFG1 $(5 \mathrm{ng} / \mathrm{g})$ and kefir-grain $(5 \mathrm{gr})$, against the same test portion without kefir-grain as a control group by holding all other factors at fixed levels. Generally, kefir-grain positively showed significant effect $\left(p=3.05 \times 10^{-5}\right)$ on AFG1 reduction (data not shown).

\section{Effect of heat-treated kefir-grain on AFG1 elimination from media}

To evaluate the ability of heat-treated kefir-grain on AFG1 elimination, the results of three levels of heating $(\mathrm{N}, \mathrm{H}$ and $\mathrm{U}$ ) were analysed by the Tukey multiple comparison test (Table 2). The results indicated that although there was no significant difference between $\mathrm{H}$ - and U-heat treatment of kefir-grain (treated at $70^{\circ} \mathrm{C}$ and $110^{\circ} \mathrm{C}$, respectively), there were significant differences between these two levels of heating and non-heated grains $(\mathrm{N})(p<0.05)$.

Figure 1 shows the positive effect of heat-treated kefirgrain $(\mathrm{H}$ and $\mathrm{U})$ on AFG1 reduction. The results revealed that with an increase in toxin and/or kefir-grain concentration at least $80 \%$ of the AFG1 removed under heattreated conditions. Several studies also reported that heat-treatment of the microorganism increased aflatoxin reduction, due to physical adsorption of the aflatoxin molecule to the cell wall components of the microorganisms
Table 1 Coded levels and actual values of the variables in central composite design

\begin{tabular}{|c|c|c|c|c|c|c|c|c|c|}
\hline \multirow[t]{3}{*}{ Run } & \multicolumn{8}{|c|}{ Design matrix } & \multirow{3}{*}{$\begin{array}{l}\text { Experimental } \\
\text { results } \\
\text { AFG1 } \\
(\%)\end{array}$} \\
\hline & \multicolumn{2}{|l|}{$x_{1}$} & \multicolumn{2}{|l|}{$x_{2}$} & \multicolumn{2}{|l|}{$x_{3}$} & \multicolumn{2}{|l|}{$\mathrm{X}_{4}$} & \\
\hline & $C$ & $A$ & $C$ & $A$ & $\bar{C}$ & $A$ & $\bar{C}$ & $A$ & \\
\hline 1 & 0 & 15 & 0 & 7.5 & 0 & 4 & 0 & 40 & 92.13 \\
\hline 2 & -1 & 10 & -1 & 5 & -1 & 2 & -1 & 30 & 88.10 \\
\hline 3 & +1 & 20 & +1 & 10 & +1 & 6 & +1 & 50 & 94.85 \\
\hline 4 & $-a^{*}$ & 5 & 0 & 7.5 & 0 & 4 & 0 & 40 & 86.00 \\
\hline 5 & +1 & 20 & +1 & 10 & +1 & 6 & -1 & 30 & 95.05 \\
\hline 6 & +1 & 20 & +1 & 10 & -1 & 2 & +1 & 50 & 91.45 \\
\hline 7 & 0 & 15 & 0 & 7.5 & 0 & 4 & $-a$ & 20 & 90.33 \\
\hline 8 & +1 & 20 & +1 & 10 & -1 & 2 & -1 & 30 & 93.15 \\
\hline 9 & -1 & 10 & +1 & 10 & +1 & 6 & -1 & 30 & 93.60 \\
\hline 10 & -1 & 10 & +1 & 10 & -1 & 2 & +1 & 50 & 94.00 \\
\hline 11 & -1 & 10 & +1 & 10 & +1 & 6 & +1 & 50 & 90.30 \\
\hline 12 & 0 & 15 & $-a$ & 2.5 & 0 & 4 & 0 & 40 & 91.60 \\
\hline 13 & 0 & 15 & 0 & 7.5 & $-a$ & 0 & 0 & 40 & 90.33 \\
\hline 14 & 0 & 15 & 0 & 7.5 & 0 & 4 & 0 & 40 & 92.07 \\
\hline 15 & -1 & 10 & +1 & 10 & -1 & 2 & -1 & 30 & 80.80 \\
\hline 16 & +1 & 20 & -1 & 5 & -1 & 2 & -1 & 30 & 90.35 \\
\hline 17 & -1 & 10 & -1 & 5 & +1 & 6 & -1 & 30 & 94.50 \\
\hline 18 & +1 & 20 & -1 & 5 & +1 & 6 & -1 & 30 & 94.05 \\
\hline 19 & -1 & 10 & -1 & 5 & -1 & 2 & +1 & 50 & 86.40 \\
\hline 20 & +1 & 20 & -1 & 5 & -1 & 2 & +1 & 50 & 91.45 \\
\hline 21 & -1 & 10 & -1 & 5 & +1 & 6 & +1 & 50 & 83.40 \\
\hline 22 & +1 & 20 & -1 & 5 & +1 & 6 & +1 & 50 & 92.15 \\
\hline 23 & 0 & 15 & 0 & 7.5 & 0 & 4 & 0 & 40 & 92.93 \\
\hline 24 & 0 & 15 & $+a$ & 12.5 & 0 & 4 & 0 & 40 & 92.07 \\
\hline 25 & $+a$ & 25 & 0 & 7.5 & 0 & 4 & 0 & 40 & 93.68 \\
\hline 26 & 0 & 15 & 0 & 7.5 & $+a$ & 8 & 0 & 40 & 94.33 \\
\hline 27 & 0 & 15 & 0 & 7.5 & 0 & 4 & $+a$ & 60 & 93.73 \\
\hline 28 & 0 & 15 & 0 & 7.5 & 0 & 4 & 0 & 40 & 90.93 \\
\hline 29 & 0 & 15 & 0 & 7.5 & 0 & 4 & 0 & 40 & 92.1 \\
\hline 30 & 0 & 15 & 0 & 7.5 & 0 & 4 & 0 & 40 & 92.1 \\
\hline 31 & 0 & 15 & 0 & 7.5 & 0 & 4 & 0 & 40 & 86.45 \\
\hline
\end{tabular}

* $a=2$.

Note: AFG1 concentration $\left(X_{1}, n g / g\right)$; kefir grain treated at $70^{\circ} \mathrm{C}\left(X_{2}, g\right)$; contact time $\left(\mathrm{X}_{3}, \mathrm{~h}\right)$; incubation temperature $\left(\mathrm{X}_{4},{ }^{\circ} \mathrm{C}\right)$; coded level $(\mathrm{C})$; actual value $(\mathrm{A})$.

[23,30-33]. However, these results were different in comparison with other reported studies which did not find any significant differences in the reduction of toxin by heattreated microorganisms [21,34-36].

In optimization step, because of the economic aspect which was related to the need for less energy consumption in the $\mathrm{H}$ condition, kefir-grain treated with $70^{\circ} \mathrm{C}$ were used. 
Table 2 Multiple comparisons of variables means on AFG1 reduction

\begin{tabular}{lllll}
\hline Comparison & Differences & Lower & Upper & Adjusted-p \\
\hline $\mathrm{H}-\mathrm{N}$ & -60.621 & -66.998 & -54.245 & $0.000^{*}$ \\
$\mathrm{H}-\mathrm{U}$ & 2.796 & -3.579 & 9.173 & 0.539 \\
$\mathrm{~N}-\mathrm{U}$ & 63.418 & 57.042 & 69.795 & $0.000^{*}$
\end{tabular}

Note: Kefir grains treated in three levels $(\mathrm{N}=$ non-heated at room temperature, $\mathrm{H}=$ heated at $70^{\circ} \mathrm{C}$ and $\mathrm{U}=$ heated at $110^{\circ} \mathrm{C}$.

*Significant at the $5 \%$ level $(p<0.05)$.

\section{Optimization and modelling of AFG1 reduction}

A CCD for the variables [AFG1 concentration $\left(\mathrm{X}_{1}\right)$, kefir-grain level $\left(\mathrm{X}_{2}\right)$, contact time $\left(\mathrm{X}_{3}\right)$ and incubation temperature $\left.\left(\mathrm{X}_{4}\right)\right]$, each at five levels with seven replicates at the centre point (to account for pure internal error and check the adequacy of curvature which offered by response), was applied for the optimization of AFG1 reduction using $\mathrm{H}$-treated-kefir grain. The design experiments for optimization using RSM are shown in Table 1.

In this stage, the concentration of spiked-AFG1 ( $\left.\mathrm{X}_{1}\right)$ applied in levels of $25 \mathrm{ng} / \mathrm{g}$ and below it (Table 3). This range was used because of the established MRL set for AFT in pistachio nuts (Iranian standard regulation $=15 \mathrm{ng} / \mathrm{g}$ and European Union legislation $=10 \mathrm{ng} / \mathrm{g}$ ) [6,7]. The ranges of $\mathrm{X}_{2}, \mathrm{X}_{3}$ and $\mathrm{X}_{4}$ were extended based on the experimental design utilized in our current investigation (Table 3 ).

Statistical parameters obtained from ANOVA were significant (Table 4). The ANOVA results indicated the adequacy of significant variables in the model. The lack-of-fit test was insignificant $(p=0.422)$. The mathematical model for response (AFG1 reduction) is shown in equation 1 :

$$
\begin{aligned}
Y= & 91.109+1.948 X_{1}+0.572 X_{2}+1.258 X_{3} \\
& +0.05 X_{4}+1.35 X_{2} X_{4}-1.712 X_{3} X_{4}
\end{aligned}
$$

Table 3 Central composite design levels of the most effective factors on AFG1 reduction

\begin{tabular}{llllll}
\hline Factor & Level & & & & \\
\cline { 2 - 6 } & $\mathbf{- a}$ & Low & Center & High & $+\mathbf{+ a}$ \\
\hline$X_{1}$ & 5 & 10 & 15 & 20 & 25 \\
$X_{2}$ & 2.5 & 5.0 & 7.5 & 10.5 & 12.5 \\
$X_{3}$ & 0 & 2 & 4 & 6 & 8 \\
$X_{4}$ & 20 & 30 & 40 & 50 & 60 \\
\hline
\end{tabular}

Note: $\left(X_{1}\right)$ toxin concentration, $\left(X_{2}\right)$ kefir grain level, $\left(X_{3}\right)$ contact time, and $\left(X_{4}\right)$ incubation temperature.

$-a$ and $+a$ are cube point levels to obtain a wider prediction space of factors.

where, $Y$ is the measured response of AFG1 reduction and $X i$ is the coded independent variables $\left(X_{1}=\right.$ AFG1 concentration, $X_{2}=$ kefir-grains level, $X_{3}=$ contact time and $X_{4}=$ incubation temperature).

Table 4 and Equation 1 show the most significant factors and interactions that affected the response. As shown in Table 4, there was a positive relationship between AFG1 concentration and its reduction $(p<0.001)$. This result was confirmed by several studies which reported a linear relationship between toxin concentration and its removal by microorganisms $[21,23]$.

The Effect plot of the model equation fitted to the interaction between toxin concentration and contact time shows in Figure 2. Contact time has a positive significant effect on response $(p<0.05)$ and AFG1 removal increased with increase in contact time. However, this result differs from those of other reports who showed that the efficiency of detoxification is not time-dependent [21,32,33,37]. This may be due to the symbiotic mixture of microbial association in kefir-grain. Hence, further studies need to demonstrate this opinion.

In this study, a significant interaction between $\mathrm{X}_{2}-\mathrm{X}_{4}$ $(p<0.05)$ and $\mathrm{X}_{3}-\mathrm{X}_{4}(p<0.01)$ were observed (Table 4$)$. Figure 3 shows contour plots of the relation between (a) toxin concentration*heating

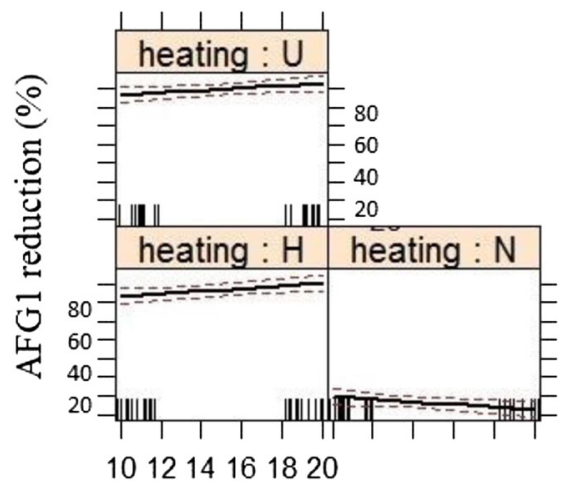

AFG1 concentration ( $\mathrm{ng} / \mathrm{g})$ (b) kefir grain*heating

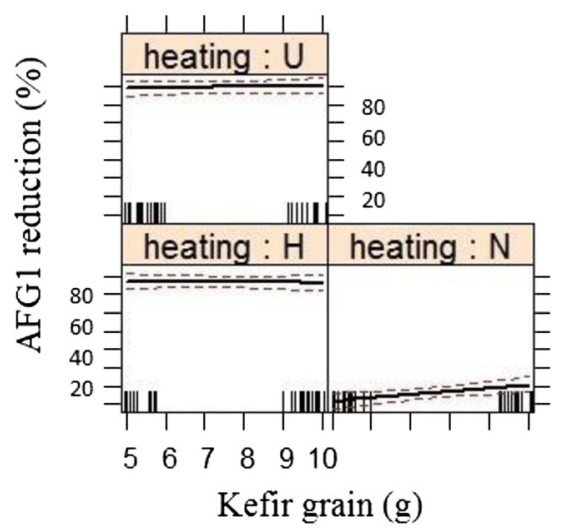

Figure 1 Effect plots of (a) toxin concentration; (b) kefir-grain level, on AFG1 reduction in three levels of heating treatments. 
Table 4 Analysis of variance and coefficient estimates for model

\begin{tabular}{|c|c|c|c|c|c|}
\hline Source of variation & Degree of freedom & Sum of squares & Mean square & $F$-value & $P$-value \\
\hline Linear & 4 & 137.032 & 34.258 & 6.041 & 0.001 \\
\hline Interaction $\left(X_{2}: X_{4}\right)$ & 1 & 29.16 & 29.16 & 5.142 & 0.032 \\
\hline Interaction $\left(X_{3}: X_{4}\right)$ & 1 & 46.923 & 46.923 & 8.275 & 0.008 \\
\hline Residuals & 24 & 136.088 & 5.67 & & \\
\hline Lack of fit & 18 & 107.232 & 5.957 & 1.238 & 0.422 \\
\hline Pure error & 6 & 28.856 & 4.809 & & \\
\hline Term & Estimate & Standard Error & $t$-value & $P$-value & Significant \\
\hline Intercept & 91.109 & 0.427 & 213.028 & 0.000 & 0.001 \\
\hline$X_{1}$ & 1.948 & 0.486 & 4.008 & 0.000 & 0.001 \\
\hline$x_{2}$ & 0.572 & 0.486 & 1.177 & 0.250 & \\
\hline$x_{3}$ & 1.258 & 0.486 & 2.588 & 0.016 & 0.05 \\
\hline$x_{4}$ & 0.05 & 0.486 & 0.102 & 0.918 & \\
\hline$X_{2}: X_{4}$ & 1.35 & 0.595 & 2.267 & 0.032 & 0.05 \\
\hline$X_{3}: X_{4}$ & -1.712 & 0.595 & -2.876 & 0.008 & 0.01 \\
\hline
\end{tabular}

Note: $\left(X_{1}\right)$ toxin concentration; $\left(X_{2}\right)$ kefir grain level; $\left(X_{3}\right)$ contact time; $\left(X_{4}\right)$ incubation temperature.

P-value: 0.0004 .

factors and response by holding all other factors at fixed levels. When kefir-grain concentrations was low $(2-5 \mathrm{gr})$, AFG1 elimination decreased with increasing incubation temperature up to around $60^{\circ} \mathrm{C}$. Also, the plot shows that using 7-8 gr kefir-grain, the percent of AFG1 reduction was constant (91\%) and increasing the temperature did not effect on response. The best reduction was in the lowest concentration of kefir-grain together with minimum temperature or in the highest concentration of kefir-grain associated with the maximum temperature (Figure 3a).

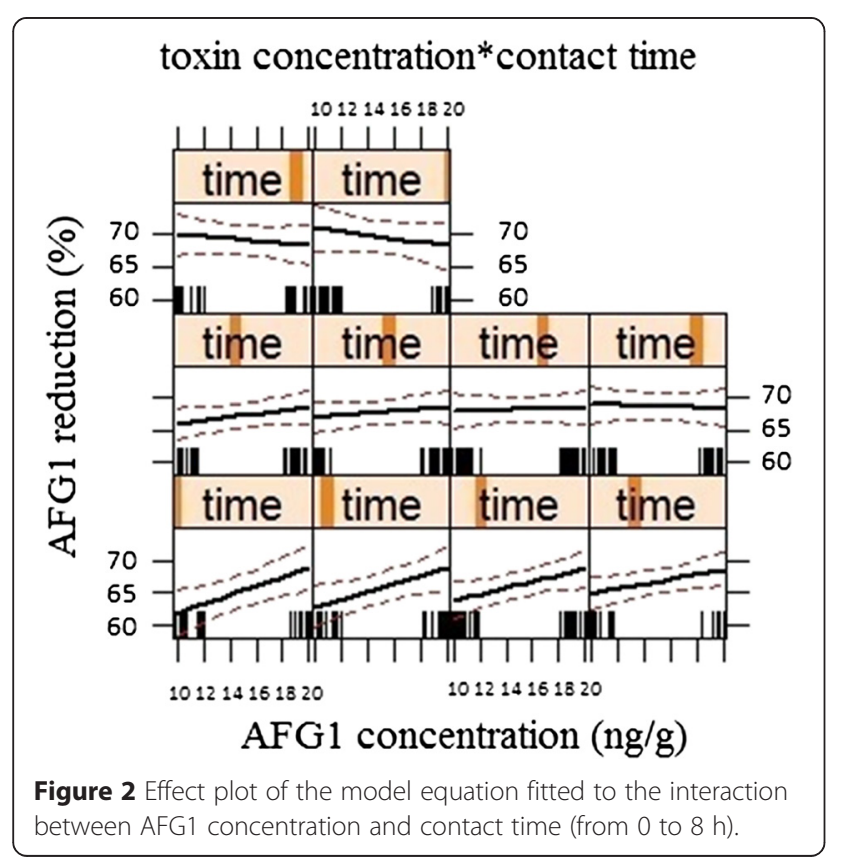

Figure 3(b) shows that AFG1 elimination increased with increasing contact time up to $6-8 \mathrm{~h}$ at minimum temperature $\left(20-30^{\circ} \mathrm{C}\right)$. However, the reduction in high temperatures $\left(50-60^{\circ} \mathrm{C}\right)$ was fast and required only a short period of time ( $94 \%$ reduction in $0-2 \mathrm{~h}$ ). It could be concluded that incubation temperature might be responsible for increasing the toxin-microorganism binding capacity.

The optimum conditions for the highest AFG1 reduction $(96.8 \%)$ were predicted by the model as follows: toxin concentration $=20 \mathrm{ng} / \mathrm{g}$, kefir-grain level $=5 \mathrm{gr}$ (equal to $10 \%$ pistachio past sample), contact time $=6 \mathrm{~h}$, and incubation temperature $=30^{\circ} \mathrm{C}$.

\section{Verification of the optimal condition}

In order to examine the predictability of the model and statistically validate the optimal conditions, agreement between the experimental (observed) and predicted value was investigated. Thus, the experimental values of the AFG1 reduction were obtained in six optimal condition replicates (mean $=94.54 \mathrm{ng} / \mathrm{g}$ ) and predicted responses calculated by equation 1 (96.7\%) compared using one sample $t$-test [38]. The $p$-value for one sample $t$-test was 0.15 , indicating that there was no significant difference between predicted amounts fitted by the model and the experimentally obtained value $(p>0.05)$.

The final step in the present study was to check the validation of the method by regression analysis under optimal conditions in six replications. The correlation coefficient $\left(R^{2}\right)$ was 97.04 , which indicated that only $2.69 \%$ of the experimental value was not explained by the optimal conditions of the model. This indicates that there is a 


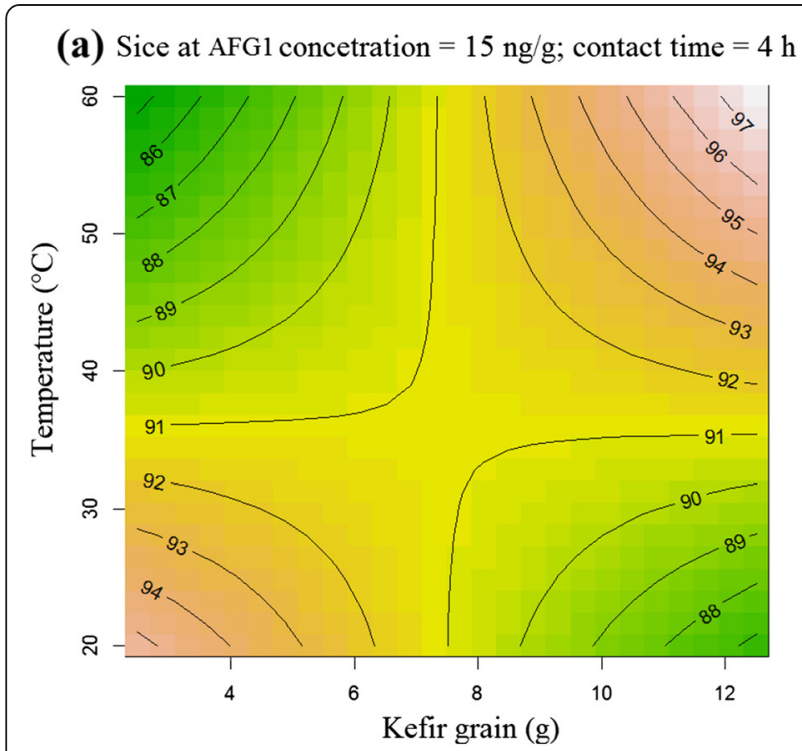

(b) Slice at AFG1 concentration $=15 \mathrm{ng} / \mathrm{g}$; kefir grain $=7.5 \mathrm{~g}$

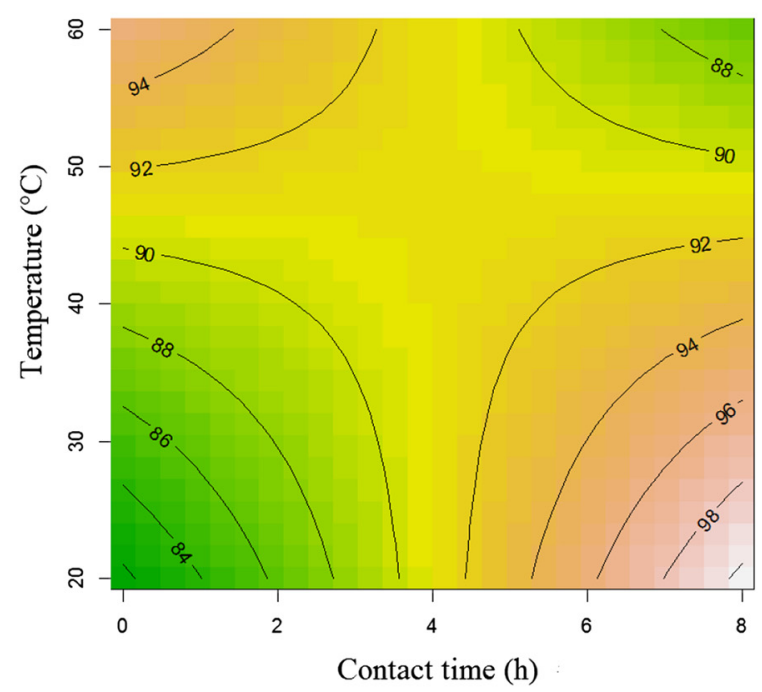

Figure 3 Contour plots of the model equation fitted to the interaction between: (a) kefir grain level and incubation temperature; (b) contact time and incubation temperature, on AFG1 reduction.

high fit degree between the value observed in the experiment and the value predicted by the model.

\section{Conclusion}

This study has provided the first evidence to demonstrate that kefir-grains have a significant effect on AFG1 decontamination from pistachio nuts. The second approach in this work was to investigate the effect of four independent variables including toxin concentration, kefir-grain level, contact time and incubation temperature on AFG1 reduction using a sequential optimization strategy (full factorial design followed by central composite design) and predict a model for optimizing the response. The results showed that both pre-heated kefir-grains at $\mathrm{H}\left(70^{\circ} \mathrm{C}\right)$ and $\mathrm{U}$ $\left(110^{\circ} \mathrm{C}\right)$ conditions caused a significant decrease in AFG1 in contaminated pistachio samples. The amount of AFG1 elimination was dependent on toxin concentration $(p<$ $0.001)$ and contact time $(p<0.05)$.

The optimization part of the study indicated that maximum AFG1 reduction (96.8\%) would be obtained in toxin concentration at $20 \mathrm{ng} / \mathrm{g}$, KG level at $10 \%$, contact time at $6 \mathrm{~h}$ and an incubation temperature at $30^{\circ} \mathrm{C}$. This result mentioned that even in low level of kefir-grain (10\%) the amount of toxin removed was high (up to $96 \%)$, suggesting that a high efficiency of microorganisms existing in kefir-grain. Consequently, the model was validated statistically and practically under optimal conditions. Six replicated experiments were conducted under optimal conditions. There was a high fit degree between experimental results and values predicted by the model $\left(R^{2}=97.04\right)$.
In conclusion, the results of our investigation showed that an optimized biological detoxification method using kefir-grains treated in $70^{\circ} \mathrm{C}$ have good accuracy and would be suitable for routine AFG1 elimination in pistachio. Consequently, the offered model can be used to predict AFG1 reduction and could be utilize to develop a strategy for reducing toxin bioavailability in pistachio nuts.

\section{Competing interests}

The authors declare that they have no competing interests.

\section{Authors' contributions}

All authors participated in conception and design, generation of data, analysis of data, interpretation of data and revision of manuscript. All authors read and approved the final manuscript.

\section{Acknowledgments}

We would like to express our appreciations to Professor R. SotudehGharebagh at the University of Tehran for their kind support of this study. The authors would like to acknowledge the support provided by "Research Council of University of Tehran" (Tehran, Iran) and also "the Research Council of College of Agriculture and Natural Resources of University of Tehran" (Karaj, Iran).

\section{Author details}

${ }^{1}$ Bioprocess and Biodetection Laboratory (BBL), Department of Food Science, Engineering and Technology, University of Tehran, 31587-77871 Karaj, Iran. 2Department of Food Science, Engineering and Technology, University of Tehran, 31587-77871 Karaj, Iran. ${ }^{3}$ Department of Food Science and Technology, Standard Research Institute, 1745-139 Karaj, Iran.

Received: 30 December 2014 Accepted: 14 April 2015

Published online: 02 May 2015

\section{References}

1. El-Zawahri MM, Morad MM, Khishin AF. Mutagenic effect of aflatoxin G1 in comparison with B1. J Environ Pathol Toxicol Oncol. 1990;10:45-51.

2. IARC, International Agency for Research on Cancer, editor. IARC Monographs on the Evaluation of Carcinogenic Risks to Humans, vol. 59: Some naturally occurring substances: food items and constituents, 
heterocyclic aromatic amines, and mycotoxins. Lyon: IARC Press; 1993. p. 245-395.

3. Report on Carcinogens: U.S. Department of Health and Human Services Public Health Service: National Toxicology Program - Aflatoxins. 12th Edition, CAS No. 1402-68-2; 2011. p. 32-4.

4. Erkmen O, Bozoglu TF. Food Microbiology 1: Microorganisms in Foods, Microbial Growth, Foodborne Diseases and Detection of Microorganisms and their Toxins. Ankara: Illke Publishing Company; 2008. p. 336. ISBN 978-605-5983-13-0.

5. Pittet A. Natural occurrence of mycotoxins in foods and feeds - an updated review. Rev Med Vet. 1998;149:479-92.

6. ISIRI, Institute of Standard and Industrial Research of I.R. Iran. Food \& Feed Mycotoxins- Maximum Tolerated level. National Standard, No. 5925. Iran: ISIRI publisher; 2010.

7. EC, European Commission. Commission Regulation (EC) No. 178/2010 of 2 March 2010, Amending regulation (EC) No 401/ 2006 as regards: groundnuts (peanuts), other oilseeds, tree nuts, apricot kernels, liquorice and vegetable oil. Off J Eur Union. 2010;L 52:32-43.

8. FAO, Food and Agriculture Organization (2012): Top production-pistachio; 2010. Database, http://faostat3.fao.org

9. Dini A, Khazaeli P, Roohbakhsh A, Madadlou A, Pourenamdari M, Setoodeh $L$, et al. Aflatoxin contamination level in Iran's pistachio nut during years 2009-2011. Food Contr. 2013;30:540-4.

10. Patel UD, Govindarajan P, Dave PJ. Inactivation of aflatoxin B1 by using the synergistic effect of hydrogen peroxide and g-radiation. J Appl Environ Microbiol. 1989;55:456-67.

11. Mukendi N, Rollmann B, Meester C. Detoxification of aflatoxin B1 by different chemical method and evaluation of the effectiveness of the treatment applied. J Pharm Belg. 1991;46:182-6.

12. McKenzie KS, Sarr AB, Mayura K, Bailey RH, Miller DR, Rogers TD, et al. Oxidative degradation and detoxification of mycotoxins using a novel source of ozone. Food Chem Toxicol. 1997;35:807-20.

13. Suzuki T, Noro T, Kawamura Y, Fukunaga K, Watanabe M, Ohta M, et al. Decontamination of Aflatoxin-forming fungus and elimination of aflatoxin mutagenicity with electrolyzed $\mathrm{NaCl}$ anode solution. J Agric Food Chem. 2002;50:633-41.

14. Zhang Q, Xiong K, Tatsumi E, Li L, Liu H. Elimination of aflatoxin B1 in peanuts by acidic electrolyzed oxidizing water. Food Contr. 2012;27:16-20

15. Hernandez-Mendoza A, Garcia HS, Steele JL. Screening of Lactobacillus casei strains for their ability to bind aflatoxin B1. Food Chem Toxicol. 2009:47:1064-8.

16. Hathout AS, Mohamed SR, El-Nekeety AA, Hassan NS, Aly SE, Abdel-Wahhab MA. Ability of Lactobacillus casei and Lactobacillus reuteri to protect against oxidative stress in rats fed aflatoxins-contaminated diet. Toxicon. 2011;58:179-86

17. Slizewska K, Nowak A, Libudzisz Z, Janusz Blasiak J. Probiotic preparation reduces the faecal water genotoxicity in chickens fed with aflatoxin B1 contaminated fodder. Res Vet Sci. 2011;89:391-5.

18. Pizzolitto RP, Salvano MA, Dalcero AM. Analysis of fumonisin B1 removal by microorganisms in co-occurrence with aflatoxin $\mathrm{B} 1$ and the nature of the binding process. Int J Food Microbiol. 2012;156:214-21.

19. Zuo RY, Chang J, Yin QQ, Wang P, Yang YR, Wang X, et al. Effect of the combined probiotics with aflatoxin B1-degrading enzyme on aflatoxin detoxification, broiler production performance and hepatic enzyme gene expression. Food Chem Toxicol. 2013:59:470-5.

20. Elsanhoty RM, Salam SA, Ramadan MF, Badr FH. Detoxification of aflatoxin M1 in yoghurt using probiotics and lactic acid bacteria. Food Contr. 2014;43:129-34

21. Pizzolitto RP, Bueno DJ, Armando MR, Cavaglieri L, Dalcero AM, Salvano MA. Binding of Aflatoxin B1 to Lactic Acid Bacteria and Saccharomyces cerevisiae in vitro: A Useful Model to Determine the Most Efficient Microorganism. In: Guevara-Gonzalez RJ, editor. Aflatoxins - Biochemistry and Molecular Biology. Chapter 16, INTECH Open Access Publisher; 2011. p. 323-46.

22. Kakisu E, Bolla P, Abrahama AG, de Urrazab P, Antoni GLD. Lactobacillus plantarum isolated from kefir: Protection of cultured Hep-2 cells against Shigella invasion. Int Dairy J. 2013;33:22-6.

23. Lee YK, El-Nezami H, Haskard CA, Gratz S, Puong KY, Salminen S, et al. Kinetics of adsorption and desorption of aflatoxin B1 by viable and nonviable bacteria. J Food Protect. 2003;66:426-30.
24. Tramšek M, Goršek A. A novel approach for assuring and following inoculums activity during kefir grains growth studies- application of dynamic pH profiles. Acta Chim Slov. 2007;54:693-9.

25. Liu J-R, Lin C-W. Production of kefir from soymilk with or without added glucose, lactose or sucrose. J Food Sci. 2000;65:716-9.

26. AOAC International. Aflatoxin B1 and Total Aflatoxins in Peanut Butter, Pistachio Paste, Fig Paste, and Paprika Powder. Immunoaffinity Column Liquid Chromatography with Post-Column Derivatization. In: Official Method analysis of AOAC international, Official Methods of Analysis, Chapter 49 Suppl. 17th ed. Gaithersburg, MD: AOAC International; 2000.

27. ISIRI, Institute of Standard and Industrial Research of I.R. Iran: Food \& Feed Determination of Aflatoxins B and G by HPLC Method and Clean up by Imminoaffinity Cloumn-Test Method. National Standard, No. 6872. , Iran: ISIRI publisher; 2011.

28. Bhoop B, Kumar R, Ahuja N. Optimizing drug delivery systems using "Design of Experiments". Part 1: Fundamental aspects. Crit Rev Ther Drug Carrier Syst. 2005:22:27-106.

29. Myers RH, Montgomery RC. Response Surface Methodology: Process and Product Optimization using Designed Experiments. New York: Wiley; 2002.

30. El-Nezami H, Kankaanpaa P, Salminen S, Ahokas J. Ability of dairy strains of lactic acid bacteria to bind a common food carcinogen, aflatoxin B1. Food Chem Toxicol. 1998;36:321-6.

31. Oatley JT, Rarick MD, Ji GE, Linz JE. Binding of aflatoxin B1 to bifidobacteria in vitro. J Food Protect. 2000;63:1133-6.

32. Shetty PH, Hald B, Jespersen L. Surface binding of aflatoxin B1 by Saccharomyces cerevisiae strains with potential decontaminating abilities in indigenous fermented foods. Int J Food Microbiol. 2007;113:41-6.

33. Rahaie S, Emam-Djomeh Z, Razavi SH, Mazaheri M. Immobilized Saccharomayces cerevisiae as a potential aflatoxin decontaminating agent in pistachio nuts. Braz J Microbiol. 2010;41:82-90.

34. Haskard CA, El-Nezami HS, Kankaanpää PE, Salminen S, Ahokas JT. Surface binding of alfatoxin B1 by lactic acid bacteria. Appl Environ Microbiol. 2001;67:3086-91.

35. Bueno DJ, Casale CH, Pizzolitto RP, Salano MA, Olivier G. Physical Adsorption of Aflatoxin B1 by lactic acid bacteria and Saccharomyces cerevisiae: a theoretical model. J Food Protect. 2007;70:2148-54.

36. Topcu A, Bulat T, Wishah R, Boyac IH. Detoxification of aflatoxin B1 and patulin by Enterococcus faecium strains. Int J Food Microbiol. 2010;139:202-5.

37. Peltonen K, El-Nezami H, Haskard C, Ahokas J, Salminen S. Aflatoxin B1 binding by dairy strains of lactic acid bacteria and bifidobacteria. J Dairy Sci. 2001;84:2152-6.

38. Rahmani A, Jinap S, Soleimany F. Validation of the procedure for the simultaneous determination of aflatoxins ochratoxin $\mathrm{A}$ and zearalenone in cereals using HPLC-FLD. Food Add Contam Part A. 2010;27:1684-93.

\section{Submit your next manuscript to BioMed Central and take full advantage of:}

- Convenient online submission

- Thorough peer review

- No space constraints or color figure charges

- Immediate publication on acceptance

- Inclusion in PubMed, CAS, Scopus and Google Scholar

- Research which is freely available for redistribution 